\title{
Nelayan Danau Tempe: \\ Strategi Adaptasi Masyarakat dalam Menghadapi Perubahan Musim
}

\author{
${ }^{1}$ Icha Musywirah Hamka, ${ }^{2}$ Hamka Naping \\ 1,2 Department Antropologi, FISIP Universitas Hasanuddin
}

Email Coresponden: chamow@ymail.com

\begin{tabular}{l}
\hline ARTICLE INFO \\
\hline Keywords: \\
Strategi Adaptasi; \\
Nelayan Danau; Musim \\
Paceklik, Danau Tempe. \\
How to cite: \\
Hamka, I.M., Naping, H. \\
(2019). Nelayan Danau \\
Tempe: Strategi ADaptasi \\
Masyarakat dalam \\
Menghadapi Kondisi \\
Perubahan Musim. \\
ETNOSIA: Jurnal \\
Etnografi Indonesia. $4(1):$ \\
59 - 72. \\
DOI: \\
10.31947/etnosia.v4i1.5485
\end{tabular}

\begin{abstract}
This article aims to describe how the economic culture of fishing communities in the area of Lake Tempe, Wajo Regency, South Sulawesi, in the face of tough times in two seasons. The existence of Lake Tempe made a lot of people who lived around him rely and making the Lake as a place to look for earnings. Its unique characteristics make Lake Tempe utilized in different ways in accordance with the seasons. It makes the community experience different issues between rainy season and dry season. This research used qualitative methods to get the depiction as a whole on the question of research. The results showed that the activity of fishing communities is changing depending on the season. It has resulted in the community get to know two of the famine, with different problems. The difference of the season brings socio-economic conditions of the difference is then also bring the community on different adaptation patterns. In the rainy season, people are faced with the problem of floods, and in the dry season, people should experience times of economic hardship. For that matter, any other uses different patterns. The rainy season, they adapt by designing the House in accordance with the conditions of the flood. They made rakkeang, bale-bale, Pallangga and patto'do. In the dry season, they overcame economic hardship by switching professions to become farmers, builders, and other informal sector jobs.
\end{abstract}

Copyright @ 2019 ETNOSIA. All rights reserved.

\section{Pendahuluan}

Danau Tempe yang terletak di Kabupaten Wajo merupakan danau terbesar di Sulawesi Selatan yang memiliki potensi ekonomi yang tinggi. Posisi geografis danau tersebut berada pada empat wilayah kecamatan, yaitu Kecamatan Tempe, Kecamatan Sabbangparu, Kecamatan Tanasitolo, dan Kecamatan 
Belawa. Pada musim hujan genangan air Danau Tempe menyatu dengan dua danau lainnya yaitu Danau Sidenreng di Kabupaten Sidrap dan Danau Buaya di Kecamatan Tanasitolo, Kabupaten Wajo. Lain halnya pada musim kemarau ketiga danau ini berpisah dengan batas-batas yang tegas. Keberadaan Danau Tempe di Kabupaten Wajo ditanggapi sebagai anugrah Tuhan oleh masyarakat disekitarnya karena danau ini telah lama dimanfaatkan sebagai sektor perikanan. Jumlah rumah yang berada di permukiman mengapung Danau Tempe adalah sebanyak 115 buah yang dihuni oleh sekitar 500 jiwa. Umumnya yang tinggal adalah nelayan yang setiap harinya disibukkan oleh aktifitas menangkap ikan dan memproses ikan basah menjadi ikan kering. (Naing, 2008, dalam Naing 2009).

Danau Tempe menjadi tempat bagi warga masyarakat sekitar danau untuk menangkap ikan air tawar. Menurut data ${ }^{1}$ yang menunjukkan bahwa, luas Danau Tempe mencapai 30.000 hektar menyediakan berbagai macam biotabiota yang bisa di konsumsi guna memenuhi kebutuhan manusia akan nutrisi. Selama kurung waktu 1948 - 1969 produksi ikan di danau ini tiap tahun mencapai 37.000 - 40.000 ton per tahun. Hingga tahun 2005 potensi perikanan Danau Tempe masih cukup besar, khususnya untuk penangkapan di perairan danau. Potensi ini relatif tetap terjaga karena restocking yang dilakukan pemerintah setiap tahun. Data statistik tahun 2006 menunjukan bahwa, produksi perikanan air tawar pada tahun 2005 mencapai 9.785 Ton. Dengan potensi hasil tangkapan nelayan sebanyak itu, melebihi kebutuhan konsumsi sehari-hari. Kelebihan hasil tangkapan nelayan dijual ke daerah lain di Sulawesi Selatan, hingga sampai ke Pulau Jawa, bahkan salah satu jenis ikan air tawarnya yaitu ikan Sidat menjadi komoditi ekspor yang cukup menjanjikan.

Selain ikan untuk konsumsi, di Danau Tempe juga hidup beragam jenis ikan hias, yang biasa di tangkap oleh nelayan sekitar dan dijual hingga ke luar negeri. Pada saat musim kemarau tiba, debit air di Danau Tempe berkurang secara signifikan, bahkan pada bagian tertentu sampai mengalami kekeringan. Pada musim kemarau tingkat kedalaman air danau rata-rata turun hingga mencapai 1-3 meter. Pada saat itu, populasi ikan dan biota danau lainnya berkurang, menjadi musim paceklik bagi nelayan karena kehilangan mata pencaharian pokok sebagai nelayan danau. Keadaan ekonomi rumah tangga nelayan danau menjadi semakin sulit. Pendapatan nelayan berkurang, bahkan sebagian nelayan tidak berpenghasilan sama sekali sehingga kebutuhan pokok sehari-hari sulit terpenuhi. Pada saat musim kemarau tiba, sebagian nelayan tinggal di rumah memperbaiki perahu dan alat tangkap yang rusak, sebagian lainnya berusaha mencari pekerjaan alternatif seperti menjadi petani.

\footnotetext{
${ }^{1}$ Alamat Web : http://laketempe.wordpress.com/lake-tempe-resources/. Diakses tanggal 10 Januari 2018
} 
Melihat kondisi Danau Tempe yang unik pada masa musim kemarau dan musim hujan. Sehingga nelayan Danau Tempe memerlukan beberapa strategistrategi adaptasi dalam merespon kondisi lingkungan tersebut. Konsep Strategi Adaptasi menurut Karta Sapoetra (1987) dalam Sitepu (2012) mengemukakan bahwa adaptasi mempunyai dua arti. Adaptasi yang pertama disebut penyesuaian diri yang autoplastis (auto artinya sendiri, plastis artinya bentuk), sedangkan pengertian yang kedua disebut penyesuaian diri yang allopstatis (allo artinya yang lain, palstis artinya bentuk). Jadi adaptasi ada yang artinya "pasif" yang mana kegiatan pribadi ditentukan oleh lingkungan, dan ada yang artinya "aktif", yang mana pribadi mempengaruhi lingkungan.

Adaptasi sendiri memiliki beberapa macam yaitu adaptasi prilaku, adaptasi fisiologi, dan adaptasi Genetika. Ketiga macam adaptasi ini merupakan cara dari manusia untuk bertahan dalam menghadapi perubahan lingkungan yang terjadi. Namun, proses adaptasi tidak akan pernah sempurna karena lingkungan akan selalu berubah-ubah, dan manusia harus selalu tetap mengikutinya menuju pada kondisi perubahan lingkungan barunya. Pada dasarnya lingkungan ini selalu berubah yang kadang-kadang perubahan terjadi dengan cepat dan kadang juga lambat. Perubahan besar yang terjadi dengan cepat mudah terlihat dan orang berusaha mengadaptasikan dirinya terhadap perubahan tersebut. Tetapi tidak selalu adaptasi tersebut berhasil yang diakibatkan perubahan yang terjadi sedikit demi sedikit secara pelan-pelan yang sukar untuk terlihat. ( Lumaksono, 2013)

Kondisi Danau Tempe adalah sebuah ekosistem yang unik karena pada musim kemarau beberapa bagian dari wilayah danau terendam air, namun pada musim kemarau berubah menjadi lahan kering yang dimanfaatkan untuk lahan perkebunan palawija, dengan ekosistem seperti itu menyebabkan masyarakat sekitar danau menjadi masyarakat yang memiliki status rangkap. Pada musim hujan mereka menjadi nelayan danau sementara pada musim kemarau mereka menjadi petani atau buruh tani. Secara akademik menjadi menarik untuk dikaji, sehingga artikel ini bertujuan untuk melihat bagaimana kondisi sosial ekonomi masyarakat nelayan Danau Tempe serta bagaimana strategi mereka dalam mengatasi berbagai kendala yang disebabkan oleh perubahan musim.

\section{Metode Penelitian}

Metode yang digunakan dalam penelitian ini adalah kualitatif dengan pendekatan etnografi. Bertujuan untuk mengkaji mengenali masalah-masalah yang dihadapi dan menjelaskan mekanisme adaptip masyarakat nelayan Danau Tempe. Instrument utama penelitian adalah peneliti sendiri. Penelitian ini dilakukan di Danau Tempe, Kabupaten Wajo, Sulawesi Selatan. Lokasi 
dipilih secara sengaja dengan alasan bahwa Danau Tempe yang merupakan danau yang terbesar di Sulawesi Selatan dengan keunikan yang terjadi pada masyarakat karena masalah yang dihadapi pada saat terjadi perubahan musim. Teknik pengumpulan data adalah Wawancara Mendalam (Indept Interview), Observasi, studi literatur. Wawancara mendalam (indept Interview), dilakukan untuk mendapatkan data-data yang terkait dengan sikap, pengetahuan, kebiasaan dan orientasi serta strategi yang digunakan oleh nelayan dalam mengatasi masalah yang dihadapi. Observasi dilakukan untuk mendapatkan data-data yang berhubungan dengan aspek sosial dan aspek fisik dari masalah yang diteliti, Studi literatur untuk mendapatkan uraian dan penjelasan konseptual teoritis yang relevan dengan masalah yang dikaji.

\section{Hasil Penelitian dan Pembahasan}

\section{- Kehidupan Masyarakat Sekitar Danau Tempe}

Masyarakat yang memiliki akses langsung dan mendiami daerah sekitar Danau Tempe terdiri atas 4 wilayah kecamatan yakni Kecamatan Tempe, Kecamatan Belawa, Kecamatan Sabangparu, dan Kecamatan Tanah Sitolo memiliki keterikatan satu sama lain. Dalam menjalankan aktivitas pengelolaan lingkungan danau mereka terikat oleh suatu sistem aturan yang telah ditetapkan dan dipatuhi secara bersama oleh mereka. Pemerintahan adat telah menetapkan aturan yang mengatur tentang bagaimana setiap warga masyarakat senantiasa saling menghormati hak dan kewajiban mereka masingmasing.

Masyarakat sekitar danau, sebagian besar bersuku Bugis. Pengaruh budaya bugis pun masih sangat kental dengan kehidupan masyarakat. Bahasa keseharian yang mereka gunakan adalah bahasa Bugis, disamping itu sebagian besar dari mereka juga mengerti berbahasa Indonesia. Meskipun tidak dipungkiri, beberapa tokoh-tokoh adat dan para orangtua tidak mengetahui berbahasa Indonesia. Oleh karena itu, Falsafah bugis, yakni siri' na pesse, juga melekat dengan kuat dalam pandangan hidup mereka. Nilai-nilai dalam siri' na pesse yang turut mereka gunakan dalam keseharian, terutama dalam berinteraksi dengan sesama masyarakat yang menggunakan danau adalah nilai-nilai sipakatau', sipakalebbi', dan sipakainge'. Sipakatau', yang berarti saling memanusiakan, menanamkan nilai-nilai saling menghormati dan menghargai martabat kemanusiaan. Nilai ini juga memberikan pengertian bahwa semua manusia pada dasarnya sama, hingga semuanya memiliki kewajiban untuk tunduk dan patuh terhadap hukum dan norma-norma yang berlaku. Sipakalebbi' atau saling memuliakan dengan menghormati status dan fungsi masing-masing dalam masyarakat, yang muda menghormati yang tua, dan sebaliknya, yang tua menyayangi yang muda, dan juga, Sipainge' yakni saling 
mengingatkan mengingatkan bahwa setiap manusia tidak luput dari keslahan dan kekhilafan, hingga semua orang membutuhkan pendapat orang lain untuk mengingatkan dan menyadarkan kesalahan-kesalahan tersebut. Untuk itu, orang-orang Bugis cenderung menghargai nasehat, kritikan ataupun saran dari siapapun yang dianggap bisa membangun. Ketiga nilai tersebut yang kemudian menjadi dasar dari prilaku masyarakat dalam berusaha menjalani kehidupan hingga menjadikan pola interaksi mereka cenderung menjadi harmonis, dan jarang terdapat konflik antara penduduk di satu wilayah dengan penduduk di wilayah lainnya.

Danau menjadi sebuah sumberdaya yang sangat penting bagi masyarakat. Danau Tempe digunakan oleh seluruh masyarakat yang ingin memanfaatkannya tanpa terkecuali. Untuk itu, peran adat menjadi sangat penting dalam mengaturnya. Para leluhur mengajarkan pentingnya danau bagi kehidupan mereka. Danau adalah sumber mata pencaharian yang diibaratkan sebagai diri sendiri. Perumpamaan danau menjadi seperti anggota badan sendiri ditujukan agar masyarakat Wajo, terutama mereka yang tinggal disekitar danau dan menggantungkan hidup mereka baik secara langsung maupun tidak terhadap danau dan biota yang ada di dalamnya, berusaha merawat dan menjaga danau seperti mereka menjaga tubuh mereka sendiri. Jikalau ada aturan-aturan danau yang dilanggar, sama artinya mereka telah melukai diri dengan tangan mereka sendiri. Bagaimanapun, ketika danau mengalami kerusakan, masyarakat sekitar danau adalah yang paling pertama terkena imbasnya. Mereka yang paling menderita kerugian atas banjir maupun kekeringan yang terjadi pada danau. Seperti yang dialami masyarakat Danau Tempe pada saat musim hujan beliau tidak meninggalkan rumah mereka hanya untuk keperluan lain seperti membeli barang sesuai keperluan mereka, hal ini sama yang disampaikan oleh para pendahulu mereka.

Danau menjadi sebuah sumberdaya yang sangat penting bagi masyarakat yang bermukim di sekitarnya. Sejak dahulu, para leluhur mengajarkan kepada masyarakat tentang pentingnya arti danau bagi kehidupan mereka. Danau adalah sumber mata pencaharian yang diibaratkan sebagai diri sendiri. Mereka mengumpamakan danau menjadi seperti anggota tubuh mereka sendiri, sehingga masyarakat Wajo, terutama mereka yang tinggal disekitar danau dan menggantungkan hidup mereka baik secara langsung maupun tidak terhadap danau dan biota yang ada di dalamnya, berusaha merawat dan menjaga danau seperti mereka menjaga tubuh mereka sendiri. Jikalau ada aturan-aturan danau yang dilanggar, sama artinya mereka telah melukai diri dengan tangan mereka sendiri.

Di Danau Tempe sendiri, belum ada industri besar yang memanfaatkan danau atau biota-biota yang ada di danau untuk keperluan industri. Aktivitas di 
danau lebih banyak digunakan oleh masyarakat sekitar yang menjadi nelayan kecil. Mereka memanfaatkan danau sebagai tempat dimana mereka mencari nafkah untuk makan sehari-hari, juga untuk dijual guna memenuhi kebutuhan mereka yang lainnya. Itulah sebabnya, mengapa tidak ada persyaratanpersyaratan khusus ataupun biaya retribusi yang di bebankan kepada nelayan. Siapapun, terutama yang berdomisili di daerah danau, bisa menjadi nelayan tanpa harus diberikan syarat-syarat khusus. Selama yang bersangkutan juga menaati segala aturan main yang ada di danau, tidak ada spesifikiasi khusus tentang orang-orang yang ingin menjadi nelayan.

\section{- Pola Aktifitas Pemanfaatan Danau Tampe}

Pengetahuan masyarakat nelayan Danau Tempe tentang segala musim sebenarnya sudah ada sejak dahulu, namun beberapa dari mereka mengatakan bahwa musim saat ini tidak bisa diprediksikan. Musim hujan kadang datang tiba-tiba padahal musim panas/kemarau. Kadang pula pada musim hujan, cuaca sangat panas seperti pada musim kemarau. Aktivitas masyarakat nelayan ini berubah-ubah tergantung pada kondisi musim. Ada 3 musim yang mereka yakini terjadi setiap tahunnya yaitu (1) Musim barat yang jatuh pada bulan November s.d April, pada bula Juni menjadi bulan persiapan memasuki musim timur, (2) pada bulan Juli s.d. September memasuki musim timur, dan (3) Musim Pancaroba pada bulan Oktober s.d. Desember.

Lokasi pemukiman para nelayan ini adalah pesisir Danau Tempe, yang secara naluriah setiap tahunnya selalu mengalami banjir, akibatnya pengalaman membentuk pengetahuan mereka yakni berdasarkan beberapa jenis sistem pengetahuan yang digunakan sebagai penanda. Sistem pengetahuan yang mereka yakni tersebut seperti formasi bintang di langit yang menjadi tanda musim barat atau timur, perilaku beberapa hewan disekitar pemukiman nelayan seperti katak yang mengeluarkan banyak bunyi berarti akan memasuki musim hujan hingga banjir dan semut yang naik ke atas rumah atau masuk ke lahan pertanian jagung yang mereka jadikan tanda-tanda untuk pengetahuan musim mereka. Aktivitas nelayan ketika mencari ikan sepenuhnya berada di Danau Tempe. Bagi masyarakat yang profesi utamanya sebagai nelayan, biasanya memiliki pola hidup yang rutin mereka lakukan dan terdapat 2 pola, aktivitas tersebut biasanya berubah akibat perubahan musim. Pola Aktivitas Pertama, Biasanya aktivitas nelayan akan dimulai pada pagi hari setelah sholat subuh. Pukul 05.00 nelayan berangkat ke danau untuk menangkap ikan, lalu pulang pada pukul 06.30 untuk menjual hasil tangkapannya. Hasil tangkapan ini biasanya dijual oleh istri dan para suami kadang memanfaatkan waktu tersebut untuk beristirahat, walaupun terkadang ada yang ikut berjualan. Pada pukul 15.00, nelayan berangkat lagi ke danau untuk memasang alat tangkapnya 
dan akan balik kerumahnya pada pukul 17.30. Pola aktivitas kedua, bagi nelayan yang memilih waktu kedua biasanya akan berangkat pada pukul 15.00 untuk memasang alat tangkap, nelayan ini pun biasanya akan bermalam di danau sembari menunggu hasil tangkapannya. Kemudian keesokan harinya pada pukul 06.00 mereka akan pulang dan hasil tangkapan ikan diberikan kepada istri untuk dijual.

Hampir seluruh pendapatan masyarakat di pesisir Danau Tempe berasal dari danau baik saat musim kemarau atau musim hujan hingga banjir. Hal tersebut menjadi bervariasi akibat perubahan musim dan menyebabkan pedapatan ekonomi pun berbeda-beda. Setiap masyarakat di pesisir pun punya cara penanganan masing-masing pada tiap musim. Bagi sebagian masyarakat nelayan di Indonesia, Musim penghujan dianggap sebagai musim paceklik, sebab angin barat yang berhembus sangat kencang seringkali menjadi hambatan bagi nelayan untuk turun melaut. Namun, bagi masyarakat nelayan Danau Tempe, di musim hujan merupakan musim penuh berkah, sebab hasil tangkapan mereka menjadi sangat melimpah. Mereka acap kali mencari ikan hanya disekitaran rumah mereka sehingga menghemat dari segi penggunaan bahan bakar. Namun, ini bukan berarti di musim penghujan masyarakat nelayan tidak mengalami masalah apa-apa. Kendala yang dihadapi masyarakat pada musim penghujan adalah banjir yang kerap kali merusak rumah-rumah dan perabotan yang mereka miliki. Untuk itu, di musim hujan, masyarakat nelayan yang bermukim di sekitar Danau Tempe memiliki pola adaptasi tersendiri.

\section{- Strategi Adaptasi Masyarakat Nelayan Terhadap Perubahan Musim}

\section{1) Musim Penghujan}

Secara umum, musim penghujan di Danau Tempe akan sangat identik dengan bencana banjir. Pada saat banjir, kondisi di Danau Tempe setiap kecamatan akan berbeda. Kecamatan yang daerahnya lebih rendah, akan terkena dampak banjir yang lebih lama. Biasanya, aktivitas masyarakat menjadi terhambat jikalau banjir datang. Selain aktivitas pertanian atau perkebunan yang gagal, sekolah diliburkan selama banjir menggenangi sekolah mereka. Di Kecamatan Sabbang Paru misalnya, informan mengatakan jika banjir terjadi, maka ia hanya tinggal dirumahnya seharian penuh. Segala aktivitas hanya berpusat di dalam rumah. Jika ada acara, misalnya pengantin atau Aqiqahan, maka mereka akan naik perahu ke rumah si empunya acara. Hampir setiap masyarakat di Kecamatan Naim memiliki perahu untuk menunjang aktivitas mereka, akibatnya ketika ada seorang anggota masyarakat mengadakan suatu acara pada saat banjir, deretan perahu akan terlihat mengelilingi panggung si empunya acara. 
Begitupun dengan pemenuhan kebutuhan sehari-hari mereka. Seperti membeli bahan pokok, biasanya jika seorang warga akan ke kota untuk membeli kebutuhan mereka, beberapa warga yang lain akan menitipakan bahan belanjaan mereka. Hal seperti itupun sebaliknya yang akan terjadi jika ada tetangga yang kota guna membeli keperluan mereka, mereka akan saling tolong-menolong.

Hampir keseluruhan rumah masyarakat pada empat kecamatan ini adalah rumah panggung adat Bugis. Meskipun sama-sama rumah panggung, rumah panggung yang ada di kecamatan yang datarannya lebih rendah ternyata berbeda dengan yang berada di dataran lebih tinggi. Informan mengemukakan bahwa, di dalam rumah mereka, tepatnya dibawah atap, ada bagian rumah yang mereka persiapkan untuk mengantisipasi banjir datang. Tempat tersebut disebut dengan rakkeang. Rakkeang sangat berfungsi besar bagi masyarakat yang bermukim di kecamatan Tempe. Dimana debit air di Kecamatan Tempe cukup besar sekitar 4-5 meter sehingga menyebabkan rumah panggung mereka yang cukup tinggi tetap terendam oleh banjir. Rakkeang menjadi tempat utama, segala bahan pokok dipindahkan ke atas rakkeang. Di rakkeang, beberapa masyarakat kecamatan Tempe memanfaatkannya sebagai ruang untuk tidur, sehingga rakkeang menjadi tempat yang sangat penting untuk aktivitas didalam rumah masyarakat kecamatan Tempe saat banjir menyerang rumah mereka. Mereka akan keluar dari rakkeang ketika mereka ingin berinteraksi dengan tetangga atau ketika mereka akan melakukan pekerjaan mereka yakni mencari ikan untuk dijual atau sekedar untuk kebutuhan makan. Rakkeang juga dapat ditemukan di wilayah Tanasitolo dan Belawa. Namun pada masyarakat di kecamatan ini, yang membuat rakkeang hanya sebagian kecil. Rakkeang dibuat hanya pada masyarakat yang rumahnya terdekat dengan danau saja, itupun hanya sebagaian kecil saja masyarakat yang dekat dengan pesisir.

Hal ini berbeda dengan Informan dari Kecamatan Sabbang Paru, menjelaskan bahwa rumah mereka tidak memerlukan rakkeang karena debit air pada saat banjir, tidak separah debit air di kecamatan Tempe. Banjir yang terjadi hanya sekitar 1 meter, sehingga tidak sampai memasuki rumah warga. Selain itu, di tempat yang letak daratannya lebih rendah, saat banjir tiba, masyarakat akan melakukan pola adaptasi dengan membuat panggung di dalam rumah mereka yang dibuat dari bahan bambu. Ini bentuknya seperti bale-bale yang diletakkan di dalam rumah. Kursi, meja, dan beberapa perabotan rumah tangga yang mereka anggap perlu untuk diamankan akan ditaruh di atas panggung bambu. Hanya barang-barang seperti motor, mobil, atau barang lainnya yang terkena banjir yang dialokasikan ke gudang besar atau mereka tampung diatas rumah mereka masing-masing. Kebiasaan 
tersebut selalu terjadi setiap tahunnya sehingga membuat masyarakat tidak merasa perlu untuk meninggalkan rumah mereka.

Adaptasi lain yang dilakukan masyarakat adalah dengan membuat Pallangga bola. Pallanga bola ini terbuat dari semen campuran batu yang dibuat untuk menahan tiang penyangga rumah. Ukurannya bervariasi, namun bentuknya selalu persegi empat. Untuk rumah masyarakat nelayan, Pallangga bola ini biasanya dibuat agak tinggi dibandingkan pallangga bola rumah bugis biasanya. Hal ini disebabkan fungsi palllangga bola bagi nelayan agar rumah mereka menjadi lebih tinggi dan terendam banjir tidak terlalu tinggi. Dengan menambahkan pallangga bola ke bawah tiang penyangga ke rumah, nelayan berharap ketika eceng gondok datang meyerbu rumah mereka saat banjir, rumah mereka tidak akan goyang karna pallangga yang kuat.

Eceng gondok adalah satu musibah bagi masyarakat nelayan ketika banjir tiba. Kekuatan dari eceng gondok mampu membuat rumah nelayan terdorong sehingga untuk mengantisispasi hal tersebut terjadi, dibuatlah patto'do itu. Patto'do terbuat dari bambu yang di pasang di sekeliling rumah. Bambu tersebut dipasang dengan tujuan arus danau tidak membawa eceng gondok dalam jumlah yang besar masuk ke area pekarangan rumah, hingga menerjang rumah nelayan. Dengan patto'do dipasang, nelayan berharap rumah mereka tidak akan dimasuki pecahan-pecahan eceng gondok, dan tertahan di pattodo.

Ketika banjir, penghasilan nelayan biasanya Rp. 200.000/hari untuk hasil yang memuaskan, namun kata informan dengan penghasilan Rp. 50.000/hari, mereka sudah membiayai kebutuhan utama keluarga. Musim hujan selalu menghasilkan ikan-ikan yang berlimpah sehingga pendapatan mereka biasanya berlimpah saat banjir. Hasil tangkapan mereka biasanya beberapa jenis ikan tersebut seperti bale salo, bale ulaweng, dan ikan Patin. Hasil tangkapan ini yang membuat mereka ketika banjir, enggan pindah ke tempat pengungsian yang telah disediakan oleh pemerintah bahkan tidak ada yang ingin pindah. Mereka merasa sudah merasa nyaman dengan rumah mereka, sebab tempat penghasilan mereka pun sangat dekat karena mereka sudah tinggal di pesisir danau. Selain itu, mereka tidak mau pindah dengan alasan kepercayaan yang diturunkan oleh nenek moyang mereka dulu. Mereka mengemukakan bahwa, mereka menganggap danau menjadi seperti anggota badan sendiri ditujukan agar masyarakat Wajo, terutama mereka yang tinggal disekitar danau dan menggantungkan hidup mereka baik secara langsung maupun tidak terhadap danau dan biota yang ada di dalamnya, berusaha merawat dan menjaga danau seperti mereka menjaga tubuh mereka sendiri. Jikalau ada aturan-aturan danau yang dilanggar, sama artinya mereka telah melukai diri dengan tangan mereka sendiri. 
Bagaimanapun, ketika danau mengalami kerusakan, masyarakat sekitar danau adalah yang paling pertama terkena imbasnya. Mereka yang paling menderita kerugian atas banjir maupun kekeringan yang terjadi pada danau. Karena itulah, masyarakat berusaha dengan sedemikian rupa tinggal dan menjaga keadaan danau meskipun banjir datang.

Alasan lain masyarakat tidak ingin pindah adalah, jika mereka jauh dari tempat pengungsian maka mereka tidak akan mendapatkan bantuan dari pihak-pihak yang prihatin. Pada saat banjir, banyak instansi-instansi yang turun untuk menyampaikan rasa prihatin sekaligus bantuan kepada mereka. Bantuan yang turun biasanya disalurkan langsung kepada peduduk di rumah-rumah mereka dalam bentuk yang bermacam-macam. Ada yang berupa uang tunai, namun kebanyakan berupa bantuan sembako, makanan instan serta pakaian dan selimut. Informasi tersebut di atas dikuatkan oleh pengakuan informan, seorang warga Kecamatan Tempe yang mengemukakan bahwa bantuan itu datang dari berbagai pihak seperti dari pemerintah setempat, Lembaga Swadaya Masyarakat (LSM) dan bahkan dari anggota masyarakat lain yang mampu. Bentuknya pun sangat beragam, namun yang paling sering adalah makanan kebutuhan sehari-hari seperti mie instan dan beras. Bahan sembako seperti mie instan, goreng, minyak, dan gula. Bahan bantuan tersebut selain berasal dari pemerintah, terkadang juga dari mahasiswa.

Meskipun tidak mau pindah dari rumahnya, wilayah, utamanya masyarakat pesisir Kecamatan Sabbang Paru dan kecamatan Tempe harus menyiapkan tempat atau gudang khusus untuk kendaraannya agar tidak rusak jika banjir melanda pemukiman mereka. Bisa juga masyarakat nelayan menitipkan kendaraan mereka di tempat yang aman dari banjir. Biasanya mereka menitipkan kendaraan di rumah keluarga ataupun kerabat mereka yang tinggal di Kota Sengkang yang letaknya lebih tinggi dari tempat kita disini sekitar danau. Meskipun tidak memakan biaya, namun kondisi seperti itu juga membuat mereka merasa tidak enak, apalagi jika banjir berlangsung hingga berbulan-bulan.

Perahu adalah satu-satunya kendaraan yang digunakan pada saat banjir. Pada beberapa masyarakat ketika kemarau, perahu sampan hanya di simpan di bawah rumah dan mulai diperhatikan kondisinya, pada saat musim penghujan telah dekat. Perahu sampan ini kemudian diperbaiki jikalau terjadi kebocoran atau di cat untuk persiapan pada saat banjir tiba. Saat banjir, perahu adalah kendaraan pokok masyarakat ini dalam beraktivitas di luar rumah. Rusnah (21 tahun) menjelaskan bahwa mereka keluar rumah pada saat banjir untuk hal-hal yang penting saja seperti keluar membeli barang kebutuhan. Kebutuhan mereka ketika banjir pun hanya dibeli ketika 
mereka sangat butuh barang tersebut karena jarak yang jauh dan menempuhnya pun harus menggunakan perahu. Hal yang penting lainnya adalah menghadiri pesta ketika ada warga yang membuat acara. Misalnya acara khitanan. Pada saat pesta, si empunya acara akan membuat sarapo (sejenis panggung), lalu masyarakat sebagai tamu akan berkumpul di rumah si empunya acara dan juga di Sarapo tersebut. Namun kata Rusnah, sangat jarang masyarakat yang membuat acara ketika banjir melanda pemukiman mereka, kebanyakan masyarakat akan lebih memilih musim kemarau. Selain itu, perahu juga digunakan untuk pekerjaan tambahan dengan menjadi supir perahu untuk masyarakat sekitar yang ingin menyebrang.

\section{2) Musim Kemarau}

Pada saat musim kemarau, aktivitas di danau pada beberapa kecamatan tetap jalan namun tidak se-intesif musim banjir dimana debit air pada musim kemarau sangat menurun. Penghasilan mereka sangat menurun. Hal ini disebabkan karena ketika debit air menurun, ikan-ikan menjadi sangat langka. Lahan danau pun sebagian berubah menjadi lahan kering sehingga sebagian masyarakat di sekitaran danau menggunakannya sebagai lahan bercocok tanam. Mereka menganggap lahan yang telah digenangi air tersebut sangat baik dan potensial untuk ditanami tanaman karena tanahnya gembur yang menyebabkan tanaman akan tumbuh subur. Hal ini membuat masyarakat nelayan berpindah profesi sementara menjadi petani ataupun kuli tani yang bercocok-tanam di pesisir Danau Tempe di tempat yang sebelumnya digenangi air. Lahan yang digunakan untuk bercocok tanam adalah pesisir danau yang mengering. Pesisir tersebut ditanami ketika debit air menurun. Lahan tersebut mereka tanami jagung, kacang kacangan dan sayur-sayuran.

Masyarakat nelayan yang berkebun di pesisir tidak menggunakan sistem perairan untuk daerah dataran yang paling rendah seperti kebun yang ditanami semangka dan kedelai. Hanya pada tanaman padi atau jagung yang terkadang menggunakan pompa untuk mengairi lahan pertanian mereka, hal ini juga disebabkan oleh lahan pertanian padi berada di dataran yang cukup tinggi dibanding lahan sayur-mayur. Lahan yang digunakan untuk bercocok tanam adalah pesisir danau yang mulai dan akan mengering. Pesisir tersebut ditanami ketika debit air menurun. Lahan tersebut mereka tanami jagung, kacang kacangan dan sayur-sayuran khusus untuk daerah dataran paling rendah sekaligus yang cukup dekat dengan air. Sedangkan untuk daerah dataran yang agak tinggi, akan mereka tanami yang memakan waktu cukup panjang proses pertumbuhannya seperti padi dan jagung. Namun bagi mereka yang mayoritas nelayan, pendapatan mereka tidak bergantung pada hasil perkebunan mereka. 
Tidak semua nelayan serta-merta dapat menjadi petani kebun karena harus memiliki modal membayar retribusi kepada Dinas Pendapatan Daerah untuk menyewa tanah danau yang mengering, sebab bagaimanapun juga, danau merupakan aset pemerintah daerah. Pemerintah daerah, dalam hal ini adalah Dinas Pertanian kemudian mengambil alih pengelolaan danau pada musim kemarau. Dinas pertanian dan perkebunan kemudian bekerja sama dengan para lurah di daerah masing-masing guna mengatur pembagian dan daerah tanam penduduk. Beberapa masyarakat nelayan Danau Tempe yang tidak sanggup membayar retribusi akan mencari penghasilan tambahan lainnya. Penghasilan tambahan tersebut seperti laki-laki berangkat ke kota untuk menjadi tukang bangunan, adapula yang menjadi tukang cat rumah. Selain itu, perempuan pun mengambil peranan. Pekerjaan tambahan juga banyak dilakukan oleh istri nelayan seperti membuat pukat dan jala, kemudian dijual dan hasilnya akan mereka gunakan untuk membeli kebutuhan sehari-hari mereka di pasar. Beberapa perempuan lainnya membuat abon ikan yang hasilnya mereka jual di kota hingga keluar Kota Sengkang. Sedangkan bagi anak-anak, mereka dibekali keterampilan dari orangtuanya atau keluarganya untuk bekerja sebagai tukang kayu pembuat perahu, tukang bemor (becak-motor) hingga beberapa anak-anak mereka mulai dapat berkerja di Kantor Kelurahan. Namun, disamping semua pekerjaaan tambahan tersebut, kebanyakan masyarakat ini lebih memilih untuk mencari ikan di danau sekalipun musim kemarau. Hasilnya untuk dijual dan beberapa hasil lainnya untuk santapan keluarga.

Selain itu, masyarakat nelayan sebelumnya telah mengantisipasi masalah perubahan musim ini dengan menyiapkan tabungan. Meskipun jumlah tabungan yang disiapkan jarang yang berjumlah besar, sebab tabungan tersebut juga mereka gunakan pada akhir musim penghujan untuk memperbaiki rumah dan perabot mereka yang hancur akibat banjir. Namun, bagi mereka, dengan adanya uang tabungan, paling tidak mereka menjadi tidak khawatir lagi dengan apa yang mereka dapat konsumsi sambil menunggu musim hujan berikutnya.

Selain masalah produksi, meskipun hampir sama pada saat musim penghujan, namun pada musim kemarau, masyarakat nelayan biasanya hanya mengambil ikan di danau untuk kepentingan konsumsi. Selain itu, mereka menanam sayuran di lahan yang kering, seperti kangkung, kacang, dan sayuran lainnya untuk konsumsi sendiri. Di musim penghujan, bahan makanan mereka dapatkan di pasar-pasar terdekat, namun, dimusim kemarau, karena kondisi keuangan mereka yang sedang memprihatinkan, mereka beradaptasi dengan jalan membuat menu konsumsi keluarga dengan bahan-bahan yang mereka dapatkan dengan menanam sendiri. Semakin kreatif para ibu rumah tangga dalam menanam dan membuat hasilnya 
menjadi konsumsi sehar-hari, semakin bijaksana mereka mengelola keuangan. Kuncinya adalah kerja sama antar anggota keluarga, agar mereka bisa melalui musim paceklik dengan baik dan mempersiapkan dirinya untu musim berikutnya yang memiliki tantangan yang berbeda.

\section{Kesimpulan}

Danau menjadi sebuah sumberdaya yang sangat penting bagi masyarakat yang bermukim di sekitarnya terutama untuk masyarakat nelayan. Sejak dahulu masyarakat menempatkan Danau Tempe sebagai bagian dari diri mereka sendiri. Meskipun begitu, Danau ini, disetiap musimnya mengharuskan masyarakat di sekitarnya, terutama masyarakat nelayan Danau Tempe harus mampu mengubah pola hidup mereka, sebab karakter Danau Tempe yang unik, sehingga mereka harus bisa beradaptasi kondisi tersebut. Berdasarkan hasil penelitian aktivitas masyarakat nelayan ini berubah-ubah tergantung pada kondisi musim. Pada musim penghujan banjir dalam keadaan tertentu dapat membawa ancaman bagi mereka sedangkan ketika musim kemarau, air di Danau Tempe menguap, hingga danau mengalami kekeringan. Populasi ikan dan biota danau lainnya akan berkurang hilang entah kemana, akibatnya nelayan merasakan panceklik yang berkepanjangan karena kehilangan mata pencaharian utama.

Perubahan air danau kemudian menjadi dasar perubahan strategi adaptasi yang dilakukan oleh masyarakat. Strategi adaptasi yang diartikan sebagai langkah-langkah penyesuaian antara individu dengan lingkungan, baik itu lingkungan alam maupun lingkungan sosial pada masyarakat sekitar Danau Tempe sangat ditentukan oleh perbedaan musim. Perbedaan musim yang membawa perbedaan kondisi sosial ekonomi tersebut kemudian membawa masyarakat pada pola adaptasi yang berbeda setiap musimnya. Pola Adaptasi pada musim penghujan mereka dimulai dengan membangun rumah berbentuk panggung, membuat rakkeang, membuat panggung di dalam rumah mereka yang dibuat dari bahan bambu untuk meletakkan perabotan Rumah Tangga serta membuat Pallangga Bola. Pada Musim kemarau masyarakat nelayan beradaptasi dengan berpindah profesi sementara menjadi petani ataupun kuli tani yang bercocok-tanam di pesisir Danau Tempe. Sebagian dari mereka juga berangkat ke kota untuk menjadi tukang bangunan. Perempuan, istri nelayan juga ikut turut mengambil peranan dengan membuat pukat dan jala, membuat abon ikan, dan lain sebagainya. Segala upaya tersebut mereka lakukan agar mereka bisa tetap bertahan, beradaptasi dalam menghadapi segala jenis musim dengan baik. 


\section{Daftar Pustaka}

Acheson, Dr. James M. (2006). Institutional Failure in Resource Management. Annual Reviews in Anthropology Vol 35, 117-134. William Durham, ed. Palo Alto, CA: Annual Reviews.

Arifin, Bustanul. (1999). Kebijakan Ekonomi Kerakyatan: Intervensi Pemerintah Dalam Sistem Pengelolaan Sumber Daya Alam. Jakarta: AMAN.

Barus, Ternala Alexander. (2007). Keanekaragaman Hayati Ekosistem Danau Toba dan Upaya Pelestariannya. Pidato Pengukuhan Guru Besar Tetap Pada Fakultas Matematika dan Ilmu Pengetahuan Alam. Medan: Universitas Sumatra Utara

Fitria, Eva. (2008). Analisis Kualitas Air dan Hubungannya dengan Keanekaragaman Vegetasi Akuatik Di Perairan Parapat Danau Toba. Tesis. Medan: Universitas Sumatera Utara

Haryono, Trijoko Sri. (2005). Strategi Kelangsungan Hidup Nelayan. Jurnal Berkala Ilmiah Kependudukan 7 (2), 126-127

Helmi, Alfian. Dkk. (2012). Strategi Adaptasi Nelayan Terhadap Perubahan Ekologis. Makara, Sosial Humaniora, Vol. 16, No. 1, Juli 2012.Hal 68-78

Lumaksono,Galih. (2013). Strategi Adaptasi Masyarakat Dalam Menghadapi Kekurangan Air Bersih (Studi Kasus Di Kampung Jomblang Perbalan Kelurahan Candi Kecamatan Candisari Kota Semarang). Skripsi. Semarang. Universitas Negeri Semarang

Naing, Naidah. (2009). Kearifan Lokal Tradisional Masyarakat Nelayan Pada pemukiman Mengapung Di Danau Tempe Sulawesi Selatan. Surabaya, Local Wisdom Volume: I, Nomor: 1. Halaman: 19 - 26, Nopember 2009

Patriana, Ratna Dkk. (2013). Pola Adaptasi Nelayan Terhadap Perubahan Iklim: Studi Kasus Nelayan Dusun Ciawitali, Desa Pamotan, Kecamatan Kalipucang, Kabupaten Ciamis, Jawa Barat. Jurnal Sosek Kp Vol. 8 No. 1 Tahun 2013. Hal 11-23

Siahaan, N.H.T. (2004). Hukum Lingkungan dan Ekologi Pembangunan. Jakarta: Erlangga

Sitepu, Lonaria. (2012). Pola Adaptasi Sosial Ekonomi Masyarakat Desa Suka Meriah Pasca Bencana Alam Gunung Sinabung. Skripsi. Medan. Universitas Sumatra Utara.

Syahfitri, Aria Mardiani. (2017). Adaptasi Sosial Masyarakat Rusunawa Kota Binjai. Skripsi. Medan. Universitas Sumatra Utara.

Ulfa, Mariam. (2018). Persepsi Masyarakat Nelayan Dalam Menghadapi Perubahan Iklim (Ditinjau Dalam Aspek Sosial Ekonomi). Jurnal Pendidikan Geografi, Tahun 23, Nomor 1, Jan 2018 , Hal 41-49. 